\title{
The Effect Of Leverage And Earning Per Share On Earning Management (A Study Of Companies Listed In Indonesia Stock Exchange)
}

\author{
Trie Nadilla ${ }^{1 *}$, Almira Keumala Ulfah ${ }^{2}$, Husna Hayati ${ }^{3}$, Shelly Midesia ${ }^{4}$, Desy Puspita ${ }^{5}$ \\ \{trienadilla0303@gmail.com ${ }^{1 *}$, almirakeumalaulfah@gmail.com ${ }^{2}$, hayatihusna@ yahoo.com ${ }^{3}$ \\ shellymidesia@yahoo.com ${ }^{4}$, andaresta.desy@gmail.com ${ }^{5}$ \} \\ 1*Islamic Finance Accounting Department, IAIN Lhokseumawe ${ }^{1}$, Indonesia \\ ${ }^{2}$ Economic Law Department, IAIN Lhokseumawe, Indonesia \\ ${ }^{3}$ Islamic Finance Accounting Department, IAIN Lhokseumawe, Indonesia \\ ${ }^{4}$ Islamic Economics and Business Faculty Department, IAIN Langsa, Indonesia \\ ${ }^{5}$ Public Sector Financial Management Department, Politeknik Kutaraja Banda Aceh, Indonesia
}

\begin{abstract}
This study investigates the relationship between leverages, earning per share (EPS) and earning management. Using discretionary accrual as a proxy for earning management. For measuring Accrual Earning Management (AEM), revenue discretionary model and revenue model (model stubben) are used in the study. The sampling technique used purposive sampling and a regression method for panel data, namely fixed effect based on the Hausman test result. Panel data regression models are applied for the period from 2016-2018 on a sample size of 31 companies listed on Indonesia stock exchange, taking LQ 45 index as a benchmark. The data analysis testing employed Eviews (Econometric View). The result showed leverage affect on the earning management negatively and earning per share (EPS) affect on the earning management positively.
\end{abstract}

Keyword : Leverage, Earning Per Share, Earning Management, LQ 45, IDX

\section{Introduction}

Managers emphasize the importance of increase in earning in the opening line of the management discussion section of the annual report [1][2]. Manager allowed to increase the value of accounting as a form of communication. Otherwise, they create opportunities for "earning management". Which select reporting method and estimates that match the firm's business economics. This study replicates previous research on earning management. Thus diverse result indicate research gap. Therefore, further research is needed to examine the relationship between leverage and earning per share (EPS) to earnings management. There studied by Kadek Marlina, Sutrisno \& Endang Mardiati, 2019)[3] conclude that company have high leverage tend to do earning management because the company is thretened with bankruptcy. Beside that the research on non bank companies listed in LQ 45 show that partially leverage have a positive effect on earning management (Joni Hendra, Heri Koesharjono \& Seger Priantono, 2018). And than the compostion of the board of directors, firm size and leverage negatively affect earned management[4]. Furthemore, earning per share (EPS) has a significant negative effect on earnings management[5]. Another research that Earning per Share (EPS) is significantly and positively influence the earning management at PT. Adhi Karya (Persero) Tbk [6]. 


\section{Methodology}

This study using purposive sampling method. The criteria include companies listed in LQ 45 of Indonesia Stock Exchange during 2016-2018 period three years in a row. During the period the companies financial \& annual reports had been accessible and audited. Also a company using Indonesian Rupiah. This paper will use panel data regrestion using EVIEWS (Economic Views). Further, there are three types of models, common effect model (CE), fixed effect model (FE) and random effects dodel (RE) that have been estimated. The most expropriate model was chosen based on the charateristic of the data to annswer the objectives of the study. The testing are Chow Test, Hausman Test, as follows:

a) Chow Test

$\mathrm{H}_{0}$ : the models follow common effect. $\mathrm{H}_{1}$ : model follow fixed effect. Decision: Decline $\mathrm{H}_{0}$ if value of prbability $<0$. Conclusion : If $\mathrm{H}_{0}$ rejected, fixed effect model better than common effect models

b) Hausman Test

$\mathrm{H}_{0}$ : the models follow common effect. $\mathrm{H}_{1}$ : model follow fixed effect. Decision : Decline $\mathrm{H}_{0}$ if value of prbability < 0 . Conclusion : If $\mathrm{H}_{0}$ rejected, fixed effect model better than common effect models relation:

The panel data regression equation model in this study we may consider the following

$\mathrm{EM}_{\mathrm{it}}: \alpha+\beta_{1}$ Leverage $_{\mathrm{it}}+\beta_{2} \mathrm{EPS}_{\mathrm{it}}+\mathrm{e}_{\mathrm{it}}$

Where :

$\mathrm{EM}_{\mathrm{it}}=$ The indicator used to measure earning management for firm $\mathrm{i}$ in year $\mathrm{t}$

$\alpha=$ constanta

$\beta_{1,} \beta_{2}=$ regression coeficient

Leverage $=$ The indicator used to measure learning management for firm $\mathrm{i}$ in year $\mathrm{t}$

EPS $=$ The indicator used to measure earning per share for firm $\mathrm{i}$ in year $\mathrm{t}$

$\mathrm{E} \quad=$ error term

In this study testing hypotheses used include testing regression coefficients together and partial regression coefficients. The research hypothesis will be accepted if $\beta \mathrm{i}(\mathrm{i}=1,2,3)=0$ : $\mathrm{H}_{0} 1$ accepted (Ha1 decline). If there is at least one $\beta \mathrm{i}(\mathrm{i}=1,2,3) \neq 0: \mathrm{H}_{0} 1$ decline $\left(\mathrm{H}_{\mathrm{a} 1}\right.$ accepted). $\mathrm{H}_{0} 1$ not decline $\left(\mathrm{H}_{\mathrm{a}} 1\right.$ decline) meaning that the independent variables together do not affect the dependent variable, whereas $\mathrm{H}_{0} 1$ decline (Ha accepted) means that the independent variables jointly influence the dependent variable. 


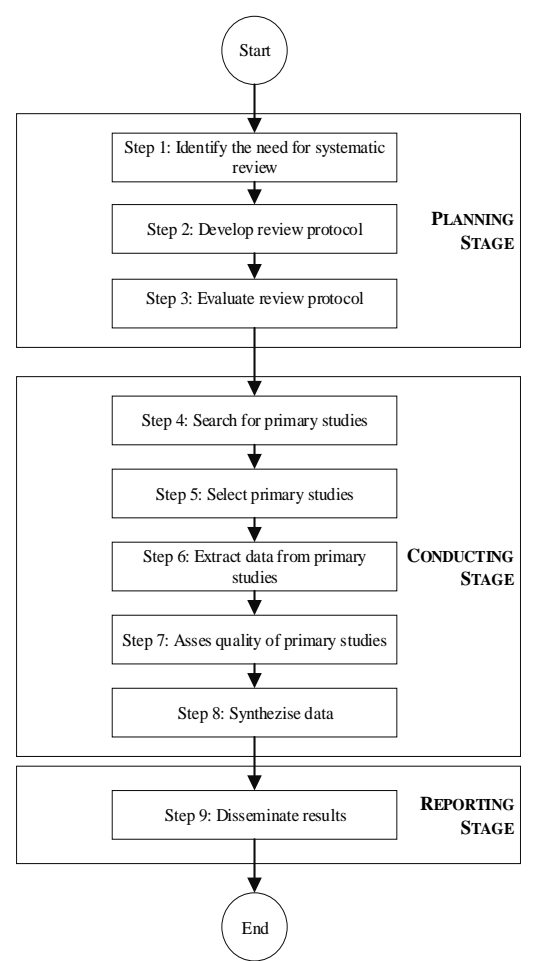

Fig.1. Systematic Review Diagram

Table 1. PICOC Criteria

\begin{tabular}{ll}
\hline $\begin{array}{l}\text { Population } \\
\text { Interventio } \\
\mathbf{n}\end{array}$ & LQ 45 Index Company \\
Compariso & $\begin{array}{l}\text { a combination of cross-sectional } \\
\text { studies with longitudinal studies } \\
\text { n }\end{array}$ \\
$\begin{array}{l}\text { (time series) } \\
\text { Outcomes }\end{array}$ & $\begin{array}{l}\text { Answer the research hypothesis } \\
\text { Context }\end{array}$ \\
\hline
\end{tabular}

Table 2. Research Question (RQ)

\begin{tabular}{lll}
\hline ID & Research Question & \multicolumn{1}{c}{ Motivation } \\
\hline RQ1 & $\begin{array}{l}\text { Does leverage, earning per } \\
\text { share effect simultaneously } \\
\text { on earning management of } \\
\text { LQ 45 in the Indonesia } \\
\text { Stock Exchange. }\end{array}$ & $\begin{array}{l}\text { To determine the effect of } \\
\text { leverage, earning per share } \\
\text { simultaneously on earning } \\
\text { management of LQ 45 in } \\
\text { the Indonesia Stock }\end{array}$ \\
RQ2 & $\begin{array}{l}\text { Does leverage on earning } \\
\text { management of LQ 45 in } \\
\text { the Indonesia Stock }\end{array}$ & $\begin{array}{l}\text { To determine the effect } \\
\text { leverage on earning } \\
\text { management of LQ 45 in }\end{array}$ \\
\hline
\end{tabular}




\begin{tabular}{|c|c|c|}
\hline & Exchange. & $\begin{array}{l}\text { the Indonesia Stock } \\
\text { Exchange. }\end{array}$ \\
\hline RQ3 & $\begin{array}{l}\text { Does earning per share on } \\
\text { earning management of LQ } \\
45 \text { in the Indonesia Stock } \\
\text { Exchange. }\end{array}$ & $\begin{array}{l}\text { To determine the effect } \\
\text { earning per share on } \\
\text { earning management of LQ } \\
45 \text { in the Indonesia Stock } \\
\text { Exchange. }\end{array}$ \\
\hline
\end{tabular}

This study used purposive sampling and panel data regression models are applied for the period from 2016 to 2018 on a sample size of 31 companies LQ 45 index listed on Indonesian Stock Exchange. The time horizon of the study is a combination of cross-sectional studies with longitudinal (time series). The data used in the study consisted of secondary data are obtained from the Indonesian Capital Market Directory-ICMD, IDX. Table 1 shows the PICOC design of the research question. The RQ in the literature review can be seen in Table 2. The mind map of the research question can be seen visually in Figure 2.

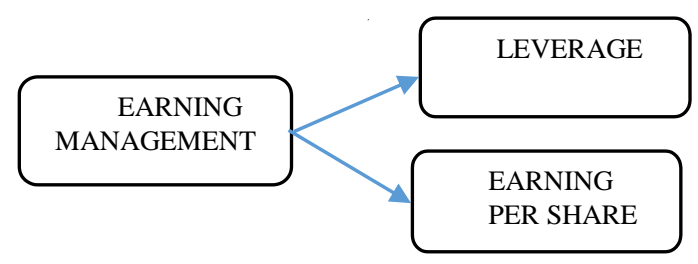

Fig.2. Mind map research question

\section{Result and Discussion}

Table 3. Result of Regression of Leverage and EPS on Earning Management

\begin{tabular}{lcrrl}
\hline \multicolumn{1}{c}{ Variabel } & Koefisien Regresi & Standar Error & t-Statistic & Prob. \\
\hline Constanta & 0.363664 & 0.083541 & 4.353148 & 0.0001 \\
\hline EPS & 0.088859 & 0.148858 & 0.596942 & 0.5528 \\
\hline Leverage & -0.961207 & 0.243776 & -3.942987 & 0.0002 \\
\hline R-Squared & 0.615979 & & & 2.795092 \\
\cline { 1 - 2 } Adjusted R-Square & 0.411169 & & & \\
\cline { 1 - 2 } F-Statistic & 3.007552 & & & \\
\hline Prob. (F-Statistic) & 0.000115 & & & \\
\hline
\end{tabular}

The results of this study of regression of Leverage and Earning Per Share (EPS) on Earning Management of hypothesis testing are the answers to the hypothesis in this study. The Regression model used in this study was the random effect model. The inferential statistical results from random effect testing are as follows.

Based on table 3 it can be seen that constant variable is 0,363664 . This constant value indicates that if leverage, earning per share and earning management are constant increase by 36\%. Then, the Durbin Watson (DW) Statistic have a value of 2,795092 indicate negative autocorrelation. 
Tabel 4. The result of Chow Test Result

\begin{tabular}{|l|l|l|l|}
\hline Effect Test & Statistic & d.f & Prob \\
\hline Cross-section F & 2.801249 & $(30,60)$ & 0.0003 \\
\hline Cross-section Chi Square & 81.442788 & 30 & 0.0000 \\
\hline
\end{tabular}

Based on Table 4 the probability value for cross-section $\mathrm{F}$ is 0.0003 . This value indicates that the probability value is smaller than the value of $\alpha=0.05$ which means that the decision taken is to use the Fixed Effect Model.

Tabel 5. The result of Hausman Test Result

\begin{tabular}{|c|l|c|l|}
\hline Test Summary & Chi-Sq.Statistic & Chi-Sq.d.f & Prob \\
\hline Cross-section random & 14.004473 & 2 & 0.0009 \\
\hline
\end{tabular}

Based on Table 5 shows that the probability is 0.0009 . This value is smaller than the value of $\alpha=0.05$ which means that Random Effect Model was not selected in this study, and the chosen model was the Fixed Effect Model.

\subsection{The Results of the Simultaneous Hypothesis Testing}

If there is at least one $\beta_{\mathrm{i}}(\mathrm{i}=1,2,3) \neq 0$, then the hypothesis is accepted. Based on regression testing, shows that the earning per share and leverage simultaneously have significant influence on earning management as it is indicated by the regression coefficient value for each variable are 0.088859 for EPS and -0.961207 for leverage.

\subsection{The Results of the Partial Hypothesis Testing}

\subsubsection{Leverage on earning management}

Table 3. shows that regression coefficient value of leverage is -0.961207 , which means that regression coefficient value of leverage is not equal to zero $\left(\beta_{\mathrm{i}}\right)$. Based on hypothesis testing, the earning per share affects the earning management if $\beta_{i} \neq 0$. Thus, it can be concluded that leverage affects the earning management. Coefficient value: -0.961207 shows that each increase in leverage by $1 \%$, it will reduce earnings management by -0.961207 assuming the earning per share variable is constant.

\subsubsection{The Effect Earning per Share on Earning Management}

Table 3. shows that regression coefficient value of earning per share is 0.088859 . It means that regression coefficient value of earning per share is not equal to zero $\left(\beta_{\mathrm{i}}\right)$. Based on hypothesis testing, the earning per share affects the earning management if $\beta_{i} \neq 0$. Thus, it can be concluded that earning per share affects the earning management. Coefficient value: 0.088859 shows that each increase in EPS by $1 \%$, it will increase earnings management by 0.088859 assuming the leverage variable is constant

\section{Conclusion}

Based on data analysis and hypotheses testing, the following conclusions are drawn: (i) leverage affects the earning management negatively; (ii) earning per share affects the earning management positively. 


\section{References}

[1] "Burgstahler, D., \& Dichev, I. (1997). Earnings management to avoid earnings decreases and losses. Journal of accounting and economics, 24(1), 99-126..pdf." .

[2] P. M. Healy, "Healy 1999," no. November, 1998.

[3] A. A. Arofah, Y. Purwaningsih, and M. Indriayu, "International journal of multicultural and multireligious understanding.," Int. J. Multicult. Multireligious Underst., vol. 5, no. 4, pp. 19-24, 2018.

[4] N. Kaushik and S. Kumar, "Leverage Effect on Earnings Management: Evidence from India," J. Account. Res. Audit Pract., vol. 17, no. 4, pp. 21-34, 2018.

[5] A. Santoso, D. Puspitasari, and R. Widyaswati, "Pengaruh Capital Intencity Ratio, Size, Earning Per Share Eps, Debt To Equity Ratio, Dividen Payout Ratio Terhadap Manajemen Laba," Fokus Ekon., vol. 11, no. 1, pp. 85-111, 2016.

[6] B. Gao and H. Zare, “No 主観的健康感を中心とした在宅高齢者における 健康関 連指標に関する共分散構造分析Title,” vol. 8, no. December, pp. 1-12, 2017. 